\title{
Estudo biomecânico em flexão da coluna cervical de cadáveres humanos submetida à corpectomia e estabilização com enxerto de fíbula
}

\author{
Cervical spine flexion biomechanical study in cadaver submitted \\ to resection of vertebral body and stabilization with fibular graft
}

\begin{abstract}
Adriano Marchetto ${ }^{1}$, Gillberto luis Camanho², Itibagi Rocha Machado ${ }^{3}$, Antonio Carlos Shimano 4 , José Baptista Portugal Paulin ${ }^{5}$, Tarcísio Eloy Pessoa de Barros Fllho 6
\end{abstract}

\section{RESUMO}

Este estudo apresenta e discute os resultados da análise biomecânica, radiográfica e anatômica de 20 peças de coluna cervical de cadáveres humanos, submetidas à corpectomia de $\mathrm{C}_{5}$, discectomia adjacente e estabilização com enxerto de fíbula. Os ensaios em flexão foram realizados em Máquina Universal de Testes. Nenhuma fratura ou extrusão do enxerto foi observada. A falha mecânica ocorreu na interface corpo vertebral-enxerto fibular, caracterizada por fratura dos corpos vertebrais adjacentes em 11 experimentos e afundamento da esponjosa em nove. O ligamento longitudinal posterior e o complexo ligamentar posterior não foram lesados em nenhuma das peças. Concluem que, em estudo experimental, o enxerto de fíbula é resistente e proporciona estabilidade imediata à coluna cervical quando submetido a carga em flexão.

Descritores: Biomecânica; coluna cervical; enxerto fibular.

\section{INTRODUÇÃO}

Os traumas em flexão são os tipos mais comuns de traumas cervicais(1). Estas lesões podem resultar em fratura do corpo vertebral, associadas ou não a instabilidade ligamentar, tornando a estabilização vertebral difícil de manter ou alcançar com métodos conservadores. Além disso, os traumas em flexão podem resultar em compressão medular secundária a fratura do corpo ou herniação discal.

Processos degenerativos, inflamatórios, infecciosos e neoplásicos também podem causar significante compressão medular, deformidade e instabilidade cervical. A gravidade poten-

\section{SUMMARY}

The authors present and discuss the results of a biomechanical, radiographic and anatomical analysis of 20 specimens, obtained from human cadaver of cervical spine submitted to $\mathrm{C}_{5}$ corpectomy, adjacent discectomy and stabilization with fibular graft. The flexion tests were carried out in the Test Universal Machine. Fracture or graft extrusion was not observed. Mechanical failure was observed in the vertebral body-fibular graft interface, characterized by fracture of the adjacent vertebral bodies in 11 experiments and depression of the cancellous bone in nine. The posterior longitudinal ligament and the posterior ligamental complex were not injured in any of the specimens. The authors concluded that, in an experimental study, the fibular graft is resistant and provides immediate stability to the cervical spine when submitted to flexion load.

Key Words: Biomechanics; cervical spine; fibular graft.

\section{INTRODUCTION}

Trauma in flexion is the most common type of cervical trauma(1). These lesions can cause fracture of the vertebral body, associated or not to ligamental instability, making vertebral stabilization difficult to be kept or obtained with conservative methods. Besides that, flexion trauma can result in medullar compression secondary to body fracture or disc herniation.

Degenerative, inflammatory, infectious and neoplastic processes can also cause significant medullar compression, deformity and cervical instability. The potential severity of the-
Estudo realizado no Laboratório de Bioengenharia da Faculdade de Medicina de Ribeirão Preto da Universidade de São Paulo

1. Mestre em Ortopedia pela FMUSP

2. Professor Livre-docente do IOT-FMUSP

3. Doutor em Medicina; Professor Adjunto da Faculdade de Medicina de Jundiaí 4. Doutor em Engenharia Mecânica; Laboratório de Bioengenharia da Faculdade de Medicina de Ribeirão Preto-USP,

5. Professor Doutor da Faculdade de Medicina de Ribeirão Preto- USP

6. Professor Associado da FMUSP

Endereço para Correspondência: Rua Barão Geraldo de Rezende, 282 cj 11 e 12 Bairro Guanabara - CEP13020-440 - Campinas - SP

E-mail: amarchetto@hotmail.com
*Work performed at Bioengineering Laboratory, College of Medicine, Ribeirão Preto, University of São Paulo

1- Master Degree in Orthopedic, FMUSP

2- Professor, IOT-FMUSP

3- Doctor Degree in Medicine, FMUSP; Adjunct Professor, College of Medicine, Jundiaí 4- Doctor Degree in Mechanical Engineering, College of Medicine, Ribeirão PretoUSP, Bioengineering Laboratory.

5- Professor Doctor, College of Medicine, Ribeirão Preto- USP

6- Associate Professor, FMUSP

Address: Rua Barão Geraldo de Rezende, 282 cj. 11 e 12

Bairro Guanabara - CEP 13020-440 - Campinas - SP

E-mail: amarchetto@hotmail.com 
cial destas situações clínicas, torna necessário a realização de procedimentos cirúrgicos para proteger a medula e raízes nervosas de danos adicionais, descomprimí-las quando necessário, restabelecer o alinhamento fisiológico e restaurar a estabilidade cervical. As falhas em estabilizar a coluna aumentam o risco de desenvolvimento de deformidades angulares e comprometimento neurólogico.

A corpectomia é amplamente utilizada nas compressões medulares e instabilidades anteriores, necessitando o defeito criado pela remoção cirúrgica do corpo vertebral, de estrutura de suporte para conferir estabilidade e restabelecer o alinhamento vertebral ${ }^{(12)}$.

Nos últimos anos, diferentes técnicas de artrodese e novos sistemas de implante foram desenvolvidos, bem como diferentes tipos e formatos de enxerto foram utilizados na tentativa de aprimorar o tratamento das desordens cervicais. No entanto, ainda são poucos os estudos na área experimental, para que possamos estabelecer qual a meIhor técnica e o tipo de enxerto a serem usados no tratamento de cada tipo de instabilidade.

Modelos biomecânicos são importantes para avaliar a eficácia de novas técnicas de estabilização precedendo sua utilização clínica. As informações obtidas podem servir como base para o desenvolvimento e aperfeiçoamento de diferentes estruturas e materiais de fixação utilizados na região cervical.

O objetivo deste estudo é propor um modelo biomecânico utilizando a coluna cervical de cadáveres humanos submetida à corpectomia de $\mathrm{C}_{5}$ e discectomia adjacente, verificar sua aplicabilidade prática e avaliar o comportamento imediato in vitro da sua estabilização com enxerto de fíbula, durante a simulação do mecanismo de flexão em Máquina Universal de Testes.

\section{MATERIAL E MÉTODOS}

Esse estudo foi realizado em 20 peças da região subaxial $\left(\mathrm{C}_{3}-\mathrm{C}_{7}\right)$ da coluna cervical de cadáveres humanos do sexo masculino. Todos os cadáveres eram adultos com óbito não acidental e não relacionados a doenças do aparelho músculoesquelético. A idade por ocasião do óbito variou de 31 a 58 anos, com média de 46 anos. Todos os cadáveres estão registrados no Serviço de Verificação de Óbitos da Capital - SP, no período de março a outubro de 2000.

As peças foram retiradas de cadáveres frescos posicionados em decúbito ventral. $\mathrm{O}$ acesso à coluna foi realizado através de uma incisão póstero-mediana na linha dos processos espinhosos, abrangendo a pele e o tecido celular subcutâneo, expondo a região do occipício até o terço superior da coluna torácica. Com o cuidado necessário, as peças da coluna vertebral de $C_{1}-T_{1}$ foram removidas, mantendo-se intactas as estruturas ósseas, musculares e ligamentares. Os enxertos fibulares foram obtidos por acesso póstero-lateral à perna de sete cadáveres com dissecação entre os músculos fibular longo e solear, ressecando-se 20 $\mathrm{cm}$ da diáfase fibular. se clinical situations demands surgical procedures in order to protect the medulla and the nerve roots from additional damage, decompress them when necessary, reestablish the physiological alignment and restore cervical stability. Failure in stabilizing the column increases the risk of angular deformities and neurological deterioration.

Removal of vertebral body is widely used in medullar compressions and anterior instabilities; the defect created by resection of the vertebral body needs a supportive structure to promote stability and reestablish the vertebral alignment ${ }^{(12)}$.

In the last few years different arthrodesis techniques and new implant systems were developed and different kinds and shapes of graft were used attempting to refine the cervical disorders treatment. Notwithstanding, experimental studies are scarce for us to establish which is the best technique and the kind of graft to be used in the treatment of all kinds of instability.

Biomechanical models are important to evaluate new stabilization techniques before clinical utilization. The information obtained can serve as a base for the development and refinement of different structures and fixation materials used in the cervical region.

The aim of this study was to propose a biomechanical model using human cadaver cervical spine undergoing C5 vertebral body removal and adjacent discectomy and access it practical applicability as well as to evaluate the immediate in vitro behavior of the stabilization with fibular bone grafting during simulation of the flexion mechanism in the Test Universal Machine.

\section{MATERIAL AND METHODS}

This study was performed in 20 specimens of the subaxial $\left(\mathrm{C}_{3}-\mathrm{C}_{7}\right)$ region of male human cadavers cervical spine. All corpses were adults and dead from non accidental and non related to musculoskeletal system causes. Age of death ranged from 31 to 58 years, average 46 years. All corpses were registered in Serviço de Verificação de Óbitos da Capital - SP, in the period from March to October 2000.

The specimens were obtained from fresh bodies in prone position. The spine was approached through a longitudinal incision over the spinal processes, involving skin and subcutaneous tissues, with exposure from the occipital bone to the upper third of thoracic spine. As carefully as necessary the spine specimens from $C_{1}-T$, were removed, keeping intact the bony, muscular and ligamental structures. The fibular grafts were obtained from legs of seven cadavers through a posterior-lateral approach, muscle divulsion and resection of 20 $\mathrm{cm}$ of fibular shaft.

The specimens were packed in plastic bags and kept frozen at $-20^{\circ} \mathrm{C}$. This procedures aim to keep physical properties of the bone, annulus fibrosus and ligaments.

In order to build the biomechanical model, each spine was removed from the freezer and left at room temperature and humidity for 12 hours, after this being submitted to removal of soft tissues of vertebral body of the first cervical 
As peças foram acondicionadas em sacos plásticos e mantidas sob congelamento à temperatura de $-20^{\circ}$ C. Este procedimento visa não alterar as propriedades físicas do osso, do ânulo fibroso e dos ligamentos.

Para confecção do modelo biomecânico, cada coluna foi retirada do congelador e colocada à temperatura e umidade ambientes por 12 horas, sendo a seguir dissecada, retirando-se as parte moles do corpo vertebral da primeira vértebra cervical e do corpo vertebral da primeira vértebra torácica, exceto a cápsula articular e ligamentos.

Realizou-se a seguir a corpectomia de $\mathrm{C}_{5}$ com serra oscilatória marca e modelo Dyonics/Smith-Nephew com lâmina curta e estreita de $2 \mathrm{~mm}$ de espessura e $1 \mathrm{~cm}$ de largura, referência $n^{\circ}$ 3704, mantendo-se intactas as articulações intervertebrais e o ligamento longitudinal posterior. Todo o material discal dos segmentos $\mathrm{C}_{4}-\mathrm{C}_{5}$ e $\mathrm{C}_{5}-\mathrm{C}_{6}$ foi removido com saca-bocado e cureta, deixando as placas terminais devidamente limpas e planas para a realização das cavidades de acoplamento do enxerto. Todas as demais estruturas capsulares, ligamentares e musculares foram deixadas intactas.

Para a preparação da cavidade inferior da placa terminal de $\mathrm{C}_{4}$ e superior da placa terminal de $C_{6}$, foi utilizado um mini-perfurador a bateria, com broca de abrasão $5.5 \times 10$ $\mathrm{mm}$ da marca e modelo Linvatec. De maneira padronizada, cavidades de 2-3 $\mathrm{mm}$ de profundidade, com largura em torno de um terço da largura do corpo vertebral e localizadas na junção do terço anterior com o médio (sentido ântero-posterior do corpo) foram criadas para receber o enxerto de fíbula.

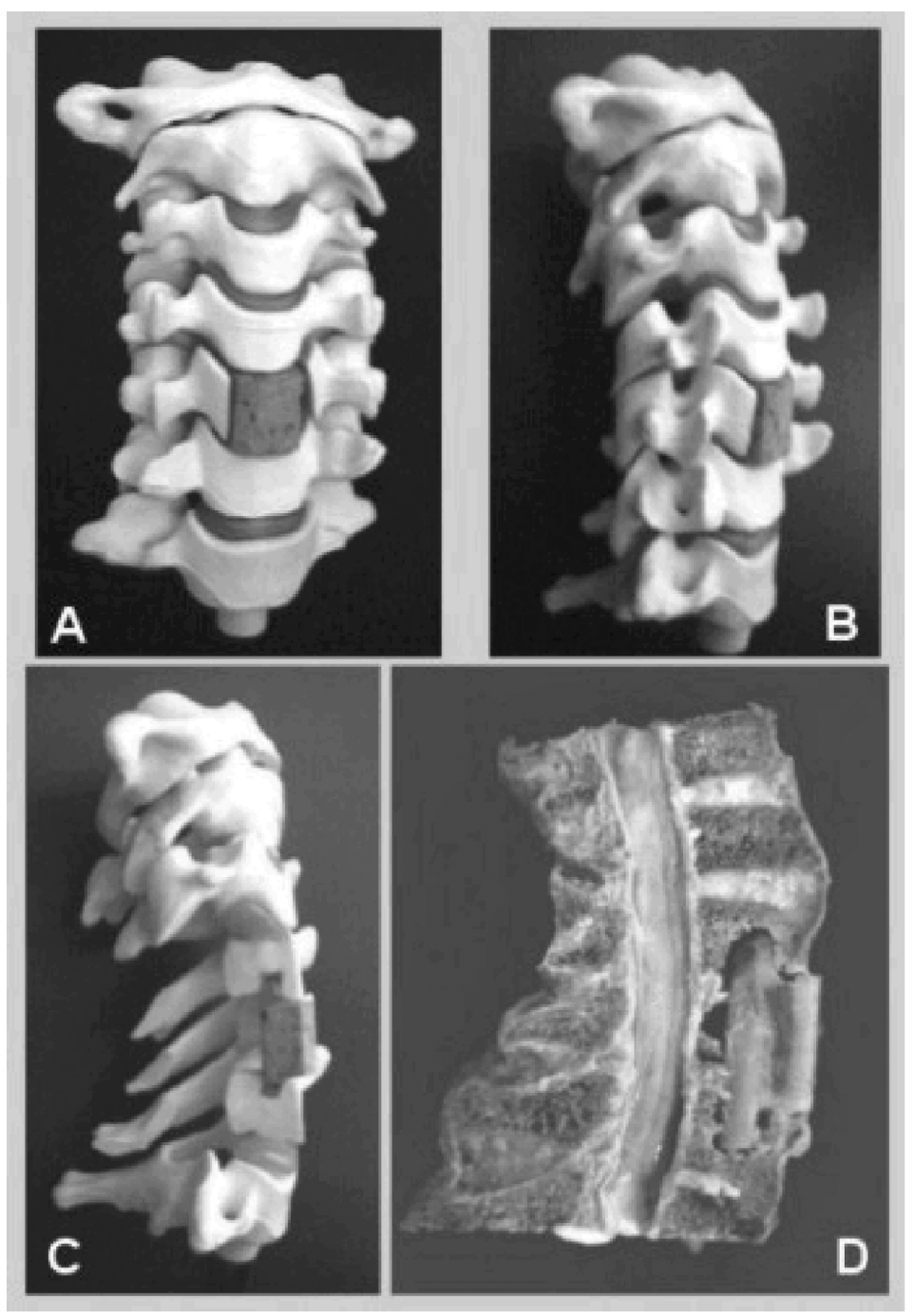

Figura 1 - Modelo plástico com o enxerto colocado: A. Vista anterior; $B$. Vista oblíqua; C. Corte sagital que permite visualizar as cavidades criadas nas vértebras adjacentes e o travamento do enxerto; $D$. Corte sagital da peça anatômica com o enxerto.

Figure 1 - Plastic mold with graft in place: A. Anterior aspect; $B$. Oblique aspect; C. Sagital cut allowing viewing the cavities created in the adjacent vertebrae and locking of the graft; $D$. Sagital cut of specimen with graft. vertebra and from the vertebral body of the first thoracic vertebra, except the articular capsule and ligaments.

Following, it was performed a corpectomy of $\mathrm{C}_{5}$ with oscillating electric saw Dyonics / Smith-Nephew with a narrow blade $2 \mathrm{~mm}$ thick and $1 \mathrm{~cm}$ wide, reference 3704, keeping intact the intervertebral joints and the posterior longitudinal ligament. All discal material of the segments $\mathrm{C}_{4}-\mathrm{C}_{5}$ and $\mathrm{C}_{5}-$ $C_{6}$ was properly removed leaving terminal plates adequately clean and plain for performing the cavities for mortising the graft. All remaining capsular, ligamental and muscular structures were untouched.

In order to prepare the inferior cavity of $\mathrm{C}_{4}$ terminal plate it was used a battery operated mini drill with an abrasion drill of $5.5 \times 10 \mathrm{~mm}$, branded Linvatec. In an standard manner cavities of 2-3 mm deep, and wide as about one third of vertebral body width, and placed in the connection of medium to anterior third (anteriorposterior) were prepared for fitting the fibular graft.

The fibular graft was prepared in its upper and inferior extremities with an oscillating Dyonics / Smith-Nephew electric saw. The notch created was 2-3 $\mathrm{mm}$ long and involved one third of fibular diameter, aiming to fit better the graft to the receptor site, allowing a better locking. The size of the graft was calculated from the measurement of the remaining space after the removal of the vertebral body and the adjacent discs from each individual specimen. The graft was placed in the receptor site under pressure, and for this it was made $1 \mathrm{~mm}$ larger than the space obtained by the corpectomy and adjacent discectomy. The final aspect of the fibular graft in the site is displayed (Figure 1). The grafts were removed from the cortical portion of fibular shaft and each fibula 
O enxerto de fíbula foi preparado por meio de cortes em suas extremidades superior e inferior com serra oscilatória modelo Dyonics /Smith-Nephew. Os entalhes criados mediam em geral 2-3 $\mathrm{mm}$ de comprimento e ocupavam um terço do diâmetro da fíbula, tendo a finalidade de adaptar melhor o enxerto ao leito receptor, permitindo melhor travamento. A medida do enxerto foi calculada a partir da medida do espaço criado após a retirada do corpo vertebral e discos adjacentes de cada peça anatômica individualmente. O enxerto era introduzido no leito receptor sob pressão, sendo, para isso, confeccionado com comprimento $1 \mathrm{~mm}$ superior ao espaço criado pela corpectomia e discectomia adjacente. O aspecto final do enxerto de fíbula no leito criado pela corpectomia de $\mathrm{C}_{5}$ é demonstrado (Figura 1). Os enxertos eram retirados da porção cortical da diáfise fibular e cada fíbula fornecia aproximadamente de quatro a cinco enxertos.

As colunas foram fixadas cefálica e caudalmente por dois fios de aço inoxidável de 1,5 $\mathrm{mm}$ de espessura cruzados perpendicularmente e englobados a um molde de polimetilmetacrilato conforme a técnica de Machado ${ }^{(15)}$.

Todas as peças com suas bases acrílicas foram radiografadas nas posições ântero-posterior e perfil para identificar e excluir peças contendo alterações ósseas indicativas de neoplasia, metástase ou fratura.

Todas as peças foram novamente acondicionadas em sacos plásticos e conservadas a temperatura de $-20^{\circ} \mathrm{C}$.

Para realização do ensaio as peças foram descongeladas à temperatura ambiente por 12 horas, e a seguir acopladas a um aparelho que permite a realização de testes em flexão(15) (Figura 2).

O aparelho de testes com a peça fixada foi adaptado à Maquina Universal de ensaios mecânicos com célula de carga Kratos de $20 \mathrm{kN}$ do Laboratório de Bioengenharia da Faculdade de Medicina de Ribeirão Preto - USP (24). À Máquina Universal, acoplou-se uma ponte de extensometria Série 200 Sodmex dotada do módulo de leitura das forças aplicadas à célula de carga, numa escala de 10 unidades para $1 \mathrm{Kgf}$. Esta ponte dispunha de um dispositivo de controle de velocidade de $5 \mathrm{~mm} / \mathrm{min}$.

Uma peça $\left(n^{\circ} 01\right)$ foi preparada para uso exclusivo como teste piloto, no qual foi verificado que o curso do eixo da Máquina Universal era suficiente para produzir falha mecânica na peça, no mecanismo de flexão. Para acomodação gave approximately four to five grafts.

The spines were fixed in their extremities by means of two stainless steel wires of 1.5 $\mathrm{mm}$ perpendicularly crossed and involved in a polymetilmetacrylate mold according to Machado's technique (15).

All specimens with their acrylic basis underwent $\mathrm{X}$-ray examination in anterior-posterior and lateral views in order to identify and exclude specimens with bony alterations suggestive of neoplasia, metastasis and fracture.

All the pieces were again packed in plastic bags and kept frozen at $-20^{\circ} \mathrm{C}$.

In order to perform the tests the specimens were defrosted at room temperature for 12 hours and following adapted to an equipment for performing flexion testing ${ }^{(15)}$ (Figure 2).

The testing equipment fixed to the specimen was placed in an Universal Machine for mechanical assay with a $20 \mathrm{kN}$ Kratos load cell from the Bioengineering Lab of Faculdade de Medicina de Ribeirão Preto - USP ${ }^{(24)}$. The Universal Machine was adapted to a Series 200 Sodmex extensiometry bridge with a reader module of the forces applied to the load cell in a 10 units to $1 \mathrm{Kgf}$ scale. This bridge had a speed control device of $5 \mathrm{~mm} / \mathrm{min}$.

One specimen (number 01) was prepared only for use as a pilot test, in which the course of the Universal Machine was found to be enough to produce a mechanical failure of the piece in the flexion mechanism. In order to accommodate the system, it was established a pre-load of $2 \mathrm{Kgf}$, which produced a starting flexion of the piece. It was standardized that all the tests would start after this pre-load. The flexion provoked in the spine during the test was measured in angles by means of an analogical reader fitted to the Testing Machine.

It was recorded, at each degree of flexion of the test, the applied load and the resulting deformation degree. The relationship between the applied load (loading cell times piece length, that represents the Flexion Momentum - MF exerted over the testing piece) and de angular deformation recorded by the angle reader was expressed by means of a mathematic equation $(15,16,27)$

The tests were stopped at the point of mechanical failure of the test represented by the sudden drop of load recording in the reader module.

After the test a new radiographic study was performed both in anterior-posterior and lateral views, in order to check the bony modifications suffered by the test body or by the 
do sistema, foi estabelecida uma pré-carga de $2 \mathrm{Kgf}$, que produzia uma flexão inicial na peça. Foi padronizado que todos os experimentos teriam início a partir desta précarga. A flexão provocada na coluna durante o ensaio, foi medida em ângulos por um módulo de leitura analógico acoplado à Maquina de Testes.

Registrou-se, a cada grau angular de flexão do ensaio, a carga aplicada e o grau de deformação resultante. A relação entre a carga aplicada (célula de carga multiplicada pelo comprimento da peça, que representa o Momento Fletor - MF exercido na peça de ensaio) e a deformação angular registrada pelo medidor de ângulos foi expressa por meio de uma equação matemática ${ }^{(15,16,27)}$.

Os ensaios foram interrompidos no ponto de falha mecânica do experimento, representado pela queda abrupta do registro de carga no módulo de leitura.

Após o ensaio, um novo estudo radiográfico foi realizado em ântero-posterior e perfil, para observar as alterações ósseas sofridas pelo corpo de prova ou pelo enxerto. Foram observados e registrados os seguintes parâmetros: migração do enxerto e fratura do enxerto, corpo vertebral, processo espinhoso, lâmina e faceta.

Para investigação das lesões internas, as peças congeladas foram retiradas de seus moldes e seccionadas no plano sagital, utilizandose uma serra elétrica com lâmina de aço inoxidável de $1 \mathrm{~mm}$ de espessura, para evitar danos às partes moles e ósseas.

A seguir, realizou-se dissecação onde foram analisadas de forma padronizada as seguintes estruturas: corpo vertebral, enxerto, disco intervertebral, canal e medula vertebral, ligamento longitudinal posterior, articulações zigoapofisárias, cápsulas articulares, ligamentos amarelo, interespinhoso e supra-espinhoso.

\section{RESULTADOS}

Na análise radiográfica pós-ensaio realizada em ânteroposterior e perfil, observamos fratura do corpo vertebral em 11 peças (Tabela 1). Nas peças números 04, 05, 06, 11,

\begin{tabular}{l|c|c|c}
\hline & Fratura C6 & Fratura C4-C6 & Ausência de fratura (A) \\
\hline Peças & 7 & 4 & 9 \\
\hline \multicolumn{3}{|c}{ A= Afundamento do osso esponjoso } & \multicolumn{2}{c}{ A= depression of the cancellous bone }
\end{tabular}

Tabela 1 - Resultado dos corpos vertebrais fraturados no estudo radiográfico pós-ensaio.

Table 1 - Result of the fractured vertebral bodies

- Post test Radiographic study.

\begin{tabular}{l|c|c|c}
\hline & FC & MF Mínimo & MF Máximo \\
\hline Peça 04 & C6 & 4.14 & 14.49 \\
\hline Peça 05 & C6 & 4.44 & 18.99 \\
\hline Peça 06 & C6 & 3.02 & 15.27 \\
\hline Peça 07 & A & 4.04 & 17.80 \\
\hline Peça 08 & C4-C6 & 3.52 & 18.87 \\
\hline Peça 09 & A & 4.47 & 19.32 \\
\hline Peça 10 & C4-C6 & 4.10 & 19.65 \\
\hline Peça 11 & C6 & 3.35 & 17.89 \\
\hline Peça 12 & A & 3.55 & 18.34 \\
\hline Peça 13 & A & 3.08 & 14.17 \\
\hline Peça 14 & A & 3.42 & 17.56 \\
\hline Peça 15 & A & 4.21 & 16.21 \\
\hline Peça 16 & C6 & 3.27 & 19.77 \\
\hline Peça 17 & C4-C6 & 3.79 & 18.76 \\
\hline Peça 18 & A & 4.23 & 18.11 \\
\hline Peça 19 & C6 & 3.62 & 17.66 \\
\hline Peça 20 & A & 3.73 & 20.68 \\
\hline Peça 21 & C4-C6 & 4.05 & 18.13 \\
\hline Peça 22 & A & 3.04 & 16.78 \\
\hline Peça 23 & C6 & 3.24 & 16.34 \\
\hline
\end{tabular}

Tabela 2 - Correlação entre o momento fletor mínimo e máximo em $\mathrm{Nm}$ com a fratura dos corpos vertebrais adjacentes ao extremo fibular. $\mathbf{F C}=$ Fratura do corpo vertebral, $\mathbf{M F}=$ Momento Fletor,

$\mathbf{N m}=$ Newton $\times$ metro, $\boldsymbol{A}=$ Afundamento do osso esponjoso adjacente ao enxerto.

Table 2 - Correlation between the minimum and the maximum flexion momentum in $\mathrm{Nm}$ to fracture of the vertebral bodies adjacent to the fibular graft.

$\mathbf{F C}=$ Vertebral body fracture, $\mathbf{M F}=$ Flexion Momentum, $\mathbf{N m}=$ Newton $\mathrm{x}$ meter, $\boldsymbol{A}=$ Depression of the cancellous bone adjacent to the graft. graft. The following parameters were observed and recorded: displacement of the graft and fracture of the graft, vertebral body, spinous process, lamina and facet.

For investigation of inside injuries, the frozen specimens were removed from their molds and cut sagitally, using an electric saw with stainless steel blade $1 \mathrm{~mm}$ thick in order to avoid injuries to soft tissues.

Following it was performed a dissection were there were analyzed in an standard way the following structures: vertebral body, graft, intervertebral discs, canal and medulla, posterior longitudinal ligament, zigoapophiseal joints, joint capsules, yellow ligament, inter-spinous and supra-spinous ligaments.

\section{RESULTS}

In the after test anterior-posterior and lateral radiographic evaluation, it was observed fracture of vertebral body 11 specimens (Table 1). In specimens number 04 , 05, 06, 11, 16, 19 and 23 the fracture occurred only in the $\mathrm{C}_{6}$ vertebral body. In specimens number 08, 10, 17 and 21 fracture occurred in $\mathrm{C}_{4}$ and $\mathrm{C}_{6}$. No fractures were observed in the spinous process, lamina, facet or fibular graft of the specimens. Anterior or posterior displacement of the graft was not evidenced.

Biomechanical analysis resulted in the 20 studied samples that the Maximum Flexion Momentum was in average $17.73 \pm 1.74 \mathrm{Nm}$ (Newton $x$ meter). Concerning degree of deformation, the average was of $30.87^{\circ} \pm$ $5.73^{\circ}$. Table 2 presents the Minimum MF for each specimen at the beginning of the test and the Maximum MF of each sample before failure of the system, correlating them to the fracture of adjacent to the graft vertebral bodies.

After the test, sagital section of the samples has shown fracture of the vertebral body anterior cortical in 11 samples, previously observed in the X-rays study. The nine remaining samples presented depression of the adjacent cancellous bone of vertebral bodies, closely contacting the incisions made on the fibular graft. Lesions in the posterior longitudinal, yellow, supraspinous and interespinous ligaments were 
16, 19, e 23 a fratura ocorreu somente no corpo vertebral de $\mathrm{C}_{6}$. Nas peças 08, 10, 17 e 21 a fratura ocorreu nos corpos de $\mathrm{C}_{4}$ e $\mathrm{C}_{6}$ conjuntamente. Não foram observadas fraturas do processo espinhoso, lâmina, faceta ou do enxerto fibular em nenhuma das peças. Nenhum caso de deslocamento anterior ou posterior do enxerto foi evidenciado.

A análise biomecânica demonstrou nas 20 peças estudadas, que o Momento Fletor Máximo foi em média 17,73 \pm $1,74 \mathrm{Nm}$ (Newton $x$ metro). Com relação ao grau de deformação, verificou-se que a média foi $30,87^{\circ} \pm 5,73^{\circ}$. A (Tabela 2) apresenta o MF Mínimo de cada peça no início do ensaio e o MF Máximo de cada peça antes da falha do sistema, correlacionando-os com a fratura dos corpos vertebrais adjacentes ao enxerto.

Após corte sagital de cada peça ao final dos ensaios, confirmamos fratura da cortical anterior do corpo vertebral em 11 peças, já visualizadas no estudo radiográfico anterior. As 9 peças restantes apresentaram afundamento na porção esponjosa dos corpos vertebrais adjacentes, intimamente em contato com os entalhes criados no enxerto fibular. Não houve lesão do ligamento longitudinal posterior, amarelo, supraespinhoso e interespinhoso em nenhuma das peças. Lesão do disco intervertebral foi observado nas peças $n^{\circ}$ s 07, 10, 14 e 15 (Tabela 3).

\section{DISCUSSÃO}

A corpectomia é amplamente aceita como método de tratamento das lesões vertebrais que apresentam instabilidade anterior ou que necessitam de descompressão da medula ${ }^{(10,12)}$. No entanto, as técnicas cirúrgicas para restaurar a estabilidade biomecânica, após a remoção do corpo vertebral, são controversas.

Enxertos de suporte são utilizados para reconstruir o segmento submetido à corpectomia, restabelecer o alinhamento anatômico e proporcionar estabilidade à coluna até que ocorra a fusão óssea

Vários locais podem servir como fonte doadora de enxerto, sendo a fíbula, a crista ilíaca e a costela os mais utilizados. Em algumas situações a estabilização cervical pode ser complementada com implantes metálicos ${ }^{(8,11)}$, metilmetacrilato $^{(28)}$ ou hidroxiapatita ${ }^{(30)}$.

O enxerto de ilíaco é o mais utilizado na coluna cervical anterior. Confeccionado de diferentes formas ${ }^{(3,7,21,26)}$, tem sido utilizado desde a década de $50 \mathrm{com}$ bons resultados clínicos. No entanto, não é tão eficiente em fornecer suporte mecânico após corpectomia. Complicações como fratura e extrusão do enxerto, e a perda do alinhamento vertebral com desenvolvimento de deformidades cifóticas tardias também são freqüentemente observadas ${ }^{(23)}$.

Por estas razões optamos pelo enxerto de fíbula para estabilizar o modelo proposto. Acreditamos que o suporte mecânico fornecido à região submetida a corpectomia é melhor em relação aos outros tipos de enxerto disponíveis, e suas características anatômicas de forma e tamanho facilitam a confecção cirúrgica e encaixe no leito receptor.

\begin{tabular}{|c|c|c|c|}
\hline $\mathrm{N}^{0}$ Peça & CV & ESP & DISCO \\
\hline 04 & C6 & - & - \\
\hline 05 & C6 & - & - \\
\hline 06 & C6 & - & - \\
\hline 07 & - & C4-C6 & $\mathrm{C} 2-\mathrm{C} 3 / \mathrm{C} 3-\mathrm{C} 4$ \\
\hline 08 & C4-C6 & - & - \\
\hline 09 & - & C4-C6 & - \\
\hline 10 & C4-C6 & - & C3-C4 \\
\hline 11 & C6 & - & - \\
\hline 12 & - & C4-C6 & - \\
\hline 13 & - & C4-C6 & - \\
\hline 14 & - & C4-C6 & $\mathrm{C} 2-\mathrm{C} 3 / \mathrm{C} 3-\mathrm{C} 4 / \mathrm{C} 6-\mathrm{C} 7$ \\
\hline 15 & - & C4 & C3-C4/C6/C7 \\
\hline 16 & C6 & - & - \\
\hline 17 & C4-C6 & - & - \\
\hline 18 & - & C4-C6 & - \\
\hline 19 & C6 & - & - \\
\hline 20 & - & C4 & - \\
\hline 21 & C4-C6 & - & - \\
\hline 22 & - & C4-C6 & - \\
\hline 23 & C6 & - & - \\
\hline
\end{tabular}

Tabela 3 - Resultados das estruturas lesadas no estudo anatômico pós-ensaio. $\mathbf{C V}=$ corpo vertebral, $\mathbf{E S P}=$ esponjosa do corpo vértebra adjacente.

Table 3 - Results of the injuried structures in the post-test anatomical study. $\mathbf{C V}=$ vertebral body, $\mathbf{E S P}=$ cancellous bone, adjacent vertebral body.

not observed. Intervertebral disc lesion was observed in specimens number 07, 10, 14 and 15. (Table 3).

\section{DISCUSSION}

Corpectomy is widely accepted as treatment method of vertebral injuries presenting anterior instability or needing medullar decompression ${ }^{(6,15,22,49)}$. Notwithstanding, the surgical techniques to restore biomechanical stability after removing the vertebral body are controversial.

Supporting grafts are used to reconstruct the segment submitted to corpectomy, reestablish the anatomical alignment and provide stability to the spine until bone healing takes place $^{(3,7,23,26)}$.

A number of sites can provide grafts, preferably the fibula, the iliac crest and ribs. In some situations, cervical stabilization can be complemented by metal implants ${ }^{(8,11)}$, methylmetacrylate ${ }^{(28)}$ or hydroxyapatite ${ }^{(30)}$. 
Alguns autores, avaliando em laboratório a resistência mecânica imediata de vários tipos de enxerto, concluem que a fíbula é aproximadamente quatro vezes mais resistente que o enxerto de crista ilíaca anterior e posterior, e que o enxerto de costela é o mais fraco de todos ${ }^{(25,30)}$. Outros, ao contrário, não observam diferença estatisticamente significativa entre a resistência da fíbula, costela e ilíaco após submetê-los a testes de compressão axial(4) .

No presente estudo, utilizamos um modelo de cadáver humano com uma condição controlada de instabilidade anterior criada por meio da corpectomia de $\mathrm{C}_{5}$ e discectomia adjacente, com o objetivo de avaliar sua aplicabilidade biomecânica para que possa ser utilizado em novos estudos na análise de diferentes tipos de estabilização.

Para testar o modelo proposto utilizamos enxerto cortical de fíbula preenchendo o defeito criado pela remoção do corpo vertebral. Avaliamos seu comportamento funcional, a resistência mecânica do sistema, a estabilização imediata alcançada, bem como a capacidade do enxerto em resistir a fratura e extrusão.

Na primeira fase de nossas investigações notamos que durante a realização do ensaio biomecânico, nenhum enxerto de fíbula sofreu fratura macroscópica, o que comprovamos na segunda fase por estudo radiográfico e anatômico. Atribuímos este fato à fíbula ser composta basicamente por osso cortical, com capacidade de fornecer suporte estrutural imediato e alta resistência às forças deformantes ${ }^{(13,14,17)}$.

Durante os ensaios, percebemos que o enxerto fibular comportou-se de forma estável e nenhum caso de deslocamento ou extrusão foi observado. Acreditamos que o entalhe criado na porção superior e inferior do enxerto permite seu travamento nos corpos adjacentes, impedindo o deslocamento durante o mecanismo de flexão quando as estruturas anteriores são comprimidas, forçando o enxerto para fora .

As placas terminais das vértebras superior e inferior devem ser removidas com cuidado, preservando ao máximo a porção anterior do corpo vertebral, que servirá de barreira mecânica à extrusão do enxerto. A remoção de quantidade excesiva de osso subcondral pode favorecer o afundamento do enxerto fibular nos corpos vertebrais adjacentes devendo, sempre, ser evitada ${ }^{(5,9)}$.

Salientamos que a ressecção óssea do leito receptor deve ser a mais econômica possível, visando apenas criar o espaço mínimo necessário para a adaptação dos entalhes e acreditamos que o limite de 2-3 mm de profundidade no osso subcondral fornece uma boa base anatômica para o travamento do enxerto, sem aumentar o risco de extrusão.

A literatura relata complicações relacionadas ao deslocamento e extrusão do enxerto fibular que contribuem para o aumento da morbidade pós-operatória ${ }^{(29)}$. Destacamos, contudo, que as técnicas de confecção e fixação do enxerto são diferentes uma das outras e, portanto, difíceis de terem seus resultados comparados.

Acreditamos que a técnica de confecção dos entalhes no enxerto e a colocação do mesmo sob pressão, preservando ao máximo a cortical anterior e esponjosa dos cor-
The iliac graft is the most used in the anterior cervical spine. Fitted into different shapes ${ }^{(3,7,21,26)}$, it has been used since the fifties with good clinical results. However, it is not very much efficient to provide mechanical support after corpectomy. Complications as fractures and extrusion of the graft and loss of vertebral alignment with the development of late kyphotic deformities are also frequently observed (23).

Considering this, we chose the fibular graft to stabilize the proposed model. We believe that the mechanical support provided to the region submitted to corpectomy is better when compared to other types of available grafts and its anatomical characteristics of shape and size facilitate adaptation at the receptor site.

Assessing in the laboratory the immediate mechanical resistance of several kinds of graft, some authors concluded that the fibula is approximately four times more resistant than the anterior and posterior iliac crest graft, and that the rib graft is the weakest $(25,30)$. Conversely, a statistically significant difference was not observed between the fibula, rib and iliac crest resistance after axial compression tests ${ }^{(4)}$.

In this study, we used a human cadaver model under controlled conditions of anterior instability created by means of $\mathrm{C}_{5}$ corpectomy and adjacent discectomy, aiming to evaluate the biomechanical applicability in order to use it in studies analyzing different kinds of stabilization.

To test de proposed model we used the fibula cortical graft, filling the defect created by the vertebral body withdrawal. We evaluated its functional behavior, the system mechanical resistance, the attained immediate stabilization, as well as the capacity of the graft to resist fracture and extrusion.

In the first phase of our investigation we noticed that during the biomechanical test, none of the fibular grafts evidenced macroscopic fracture, and this was confirmed in the second phase by the radiographic and anatomical study. This was attributed to the fibula basically consists in cortical bone, being able to provide immediate structural support and high endurance to deforming forces ${ }^{(13,14,17)}$.

During the tests the fibular graft presented stable behavior and displacement or extrusion were not observed. We believe that the notch made in the superior and inferior part of the graft allows it to lock in the adjacent bodies, preventing displacement during the flexion mechanism when the anterior structures are compressed, pushing the graft outwards.

Terminal plates of superior and inferior vertebrae should be carefully removed, preserving to the most anterior portion of the vertebral body, that will pose a mechanical barrier to graft extrusion. Excessive removal of subcondral bone may allow the graft to depress into adjacent vertebral bodies, and thus must be avoided (5, 9).

We emphasize that bone resection of the receptor site must be the most economical as possible, aiming only to create the minimum space necessary to the adaptation of the notch and we believe that the limit of 2-3 $\mathrm{mm}$ depth in the subchondral bone provides a good anatomical basis for the graft to lock, not increasing the risk of extrusion. 
pos vertebrais adjacentes, pode contribuir de forma significativa para a diminuição desta complicação.

Os testes foram realizados em flexão por acreditarmos que este movimento é o mais próximo do mecanismo de trauma e, portanto, capaz e avaliar a coluna cervical sob condições semelhantes às observadas na clínica; ao contrário da literatura que, na maioria das vezes, realiza testes com carga de compressão axial (4,19,20,22).

A análise biomecânica dos ensaios, em decorrência da deformação ser angular e cada coluna apresentar comprimento diferente, foi realizada através de Momento Fleto ${ }^{(18)}$, que é uma resultante utilizada para documentar a variação de carga durante a angulação do ensaio. Cada ângulo de deformação da peça apresenta um Momento Fletor próprio, calculado por meio de uma equação matemática desenvolvida por bioengenheiros ${ }^{(15,16,27)}$.

Embora saibamos que as estruturas que compõem a coluna cervical são visco-elásticas e esta propriedade, juntamente com a resistência óssea, tende a diminuir com a idade $^{(2,15)}$, ao analisarmos nossos resultados, observamos que a deformação dos conjuntos, que biomecanicamente corresponde à elasticidade dos mesmos, apresentou comportamento homogêneo. Uma possível explicação para este fato é que a idade das peças é similar.

O Momento Fletor Médio Máximo (MFMM), também apresentou comportamento homogêneo nas vinte peças testadas. A média de idade relativamente baixa e a utilização de colunas provenientes apenas de cadáveres do sexo masculino, contribuíram para a menor variabilidade dos resultados $^{(2)}$.

O estudo experimental(15) realizado em 1993, flexiona colunas cervicais normais de cadáveres humanos até o ponto de falha e demonstra que o grupo do sexo masculino com faixa etária entre 35-40 anos apresenta MFMM de 19,78 $\mathrm{Nm}$; enquanto o grupo com faixa etária entre 55-60 anos apresenta MFMM de 16,21 Nm. Nossos resultados apresentam um MFMM de $17,73 \mathrm{Nm}$, o que nos permite proferir que o modelo estabilizado com enxerto de fíbula apresenta resistência similar à coluna normal, já que ambos os estudos foram realizados no mesmo laboratório e com a mesma metodologia.

O estudo radiográfico pós-ensaio, permitiu-nos confirmar a ausência de fratura ou migração do enxerto fibular. As peças nos 04, 05,06, 08, 10, 11, 16, 17, 19, 21 e 23 apresentaram fratura na cortical anterior dos corpos vertebrais adjacentes ao enxerto, sugerindo menor resistência do corpo vertebral em relação ao enxerto de fíbula. Nas peças nos $08,10,17$, e 21 a fratura ocorreu nos corpos de $\mathrm{C}_{4}$ e $\mathrm{C}_{6}$ simultaneamente, enquanto as peças restantes apresentaram fratura somente de C6. Não conseguimos estabelecer uma relação direta das cargas aplicadas com o dano ósseo constatado. Algumas peças que sofreram afundamento da sua porção esponjosa necessitaram maior carga para provocar a falha mecânica (Momento Fletor Máximo maior) do que as peças que apresentaram fratura da cortical anterior
The literature reports complications related to fibular graft displacement and extrusion which contributes to increase post-operative morbidity ${ }^{(29)}$. We stress, however, that the techniques of making and fixating grafts are different and thus it is difficult to compare the results.

We think that the technique to make the notch in the graft and its placement under pressure, preserving to the most the anterior cortical and the cancellous bone of the adjacent vertebral bodies can significantly contribute to avoid this kind complication.

The tests were carried out in flexion because we believe that this movement is the most similar to the trauma mechanism being thus able to evaluate the cervical spine under similar conditions to those observed in the clinic; conversely, in the literature most of the tests were performed with axial compression load $(4,19,20,22)$.

Biomechanical analysis of the tests, due to angular deformation and different length of the spines, was carried out using the Flexion Momentum (18), a resultant used to detect the load variation during angulation. Each deformation angle of the specimen presents its own Flexion Momentum, calculated by means of a mathematic equation developed by bioengineers ${ }^{(15,16,27)}$.

Although it is known that the structures composing the cervical spine are viscoelastic and this property and bone resistance tend to decrease with ageing ${ }^{(2,15)}$, when analyzing our results it is observed that deformation which biomechanically corresponds to elasticity presented an homogeneous behavior. A possible explanation is that the age of the specimens was similar.

The Maximum Mean Flexion Momentum (MFMM) also presented an homogeneous behavior in the twenty tested specimens. The relatively low mean age and the use of spines from male cadavers contributed to a lower variability of the results, agreeing with ${ }^{(2)}$.

The experimental study ${ }^{(15)}$ performed in 1993 caused flexion of normal cervical spine of human cadavers to the collapse point demonstrates that the group of males with ages ranging 35 to 40 years presented a MFMM of $19.78 \mathrm{Nm}$ while the group aged between 55 and 60 years old presented a MFMM of $16.21 \mathrm{Nm}$. Our results present a MFMM of 17.73 $\mathrm{Nm}$, thus allowing us to say that the model with fibular grafting stabilization presents an endurance that is similar to normal spine, since both studies were performed at the same laboratory and used the same methodology.

The post-test $X$-rays study allowed us to confirm the absence of fracture or migration of the fibular graft. Samples number 04, 05, 06, 08, 10, 11, 16, 17, 19, 21 and 23 presented fracture of anterior cortical of vertebral bodies, adjacent to the graft, suggesting that the vertebral body is less resistant when compared to the fibular graft. In samples number 08, 10, 17 and 21 the fracture occurred in $C_{4}$ and $C_{6}$ simultaneously while the remaining samples presented fracture only in $C_{6}$. We could not establish a direct relationship of the applied loads to the observed damage. Some specimens 
dos corpos vertebrais de $\mathrm{C}_{4}$ e $\mathrm{C}_{6}$ (Tabela 2). Este fato deve ser estudado posteriormente devido à necessidade de análise biomecânica mais detalhada. Não observamos fratura avulsão do processo espinhoso, lâmina ou faceta em nenhum dos ensaios.

Nas peças números $07,09,12,13,14,15,18,20$ e 22, observamos afundamento da região esponjosa superior ou inferior, intimamente em contato com os entalhes criados no enxerto. Acreditamos que o afundamento do tecido esponjoso ocorreu pela compressão exercida pelos entaIhes do enxerto, e foi responsável pela a falha mecânica antes que ocorresse a fratura da cortical anterior dos corpos vertebrais. Alguns autores ${ }^{(37)}$ sugerem que as construções com enxerto fibular podem falhar na interface corpo vertebral-enxerto fibular, devido a maior rigidez do osso cortical da fíbula em relação ao tecido esponjoso dos corpos vertebrais adjacentes.

Nossa análise anatômica não evidenciou lesão do ligamento longitudinal posterior e complexo ligamentar posterior em nenhuma das peças, apesar de realizarmos testes até o ponto de falha. Acreditamos que a falha ocorreu na transição corpo-enxerto antes que ocorresse lesão ligamentar posterior.

A aplicação de forças deformantes em flexão, faz com que a coluna cervical sofra compressão anterior e distração posterior. Os ligamentos posteriores têm sua tensão aumentada durante a flexão cervical favorecendo a ruptura, fato que não observamos em nenhum dos ensaios. Nas 20 peças testadas, apenas as estruturas anteriores falharam.

Os discos intervertebrais também sofrem a ação compressiva anterior durante o mecanismo de flexão. Observamos lesão discal nas peças números 07, 10, 14 e 15 (Tabela 3), provavelmente pelo aumento da pressão interna exercido pela carga aplicada. Estas lesões foram acompanhadas de achatamento das placas terminais adjacentes, no entanto sem protrusão discal para dentro do canal medular, concordando com o estudo ${ }^{(20)}$ que afirma que o corpo vertebral é menos resistente à compressão que o disco normal e que o núcleo pulposo, sob pressão, provoca protrusão da placa terminal em direção ao centro do corpo vertebral até a falha óssea. É importante salientarmos que estas peças também apresentaram afundamento da esponjosa em contato com os entalhes ósseos, tornando difícil avaliar qual estrutura foi responsável pela falha mecânica, ou se houve a combinação de ambas.

Modelos biomecânicos são importantes para a avaliação das estabilizações cervicais, no entanto, sua correlação clínica ainda não se encontra totalmente definida. A escolha apropriada da técnica de estabilização e do tipo de enxerto ósseo no tratamento das lesões cervicais são de fundamental importância para o êxito terapêutico. O desafio que permanece, é simular de forma precisa o complexo funcionamento cervical e as condições de carga observadas in vivo, com o objetivo de obter avaliações biomecânicas mais eficazes. that presented depression of cancellous bone needed a higher load to cause mechanical failure (a bigger Maximum Fexion Momentum) than specimens presenting with fracture of anterior cortical of vertebral bodies of $\mathrm{C}_{4}$ and $\mathrm{C}_{6}$ (Table 2). This should be additionally studied due to need of a more detailed biomechanical analysis. It was not observed any avulsion fracture of spinous processes, lamina or facet in any of the assays.

In samples number 07, 09, 12, 13, 14, 15, 18, 20 and 22, we observed depression of the superior or inferior cancellous bone, in close contact with the notch made on the graft. We believe that depression of the cancellous bone took place due to the compression of the graft notch and was responsible for the mechanical failure before the fracture of anterior cortical of the vertebral bodies. Some authors (37) suggest that some constructions with fibular grafting may fail in vertebral body-fibular graft interface due to cortical bone of fibular graft is more rigid than the cancellous bone of adjacent vertebral bodies.

Our anatomical analysis did not evidence injuries of the posterior longitudinal ligament and posterior ligamental complexes, though the tests were effected until failure. We believe that failure occurred in the transition body-graft before posterior ligamental injury took place.

Application of flexion deforming forces, makes the cervical spine to suffer anterior compression and posterior distraction. The posterior ligaments have their tension increased during cervical flexion favoring rupture, what was not observed in any assay. In the twenty samples tested, only the anterior structures failed.

The intervertebral discs are also submitted to the anterior compressive force during the flexion mechanism. We observed disc injuries in samples number 07, 10, 14 and 15 (Table 3), probably due to increased internal pressure exerted by the applied load. These injuries were joined by flattening of the adjacent terminal plates without disc protrusion inwards the medullar canal, agreeing with the study ${ }^{(20)}$, that states that the vertebral body is less resistant to compression than the normal disc and that the pulp nucleus under pressure provokes terminal plate protrusion into the center of the vertebral body until bone failure. It is important to highlight that these samples also presented cancellous bone depression in contact with the notch in the bone, making difficult to evaluate whether only one or both structures were responsible for the mechanical failure and which one.

Biomechanical models are important for evaluation of cervical stabilizations, however its correlation to clinics is not yet totally established. Choice of appropriated stabilization technique and type of bone grafting is of fundamental importance for therapeutic success. The challenge that remains is to simulate in a precise way the functional cervical complex and the load conditions observed in vivo aiming to obtain more efficacious biomechanical evaluation. 


\section{CONCLUSÃO}

Concluem que o modelo biomecânico testado demonstrouse adequado à finalidade proposta, podendo ser utilizado para análise de diferentes tipos de estabilização cervical e que o enxerto cortical de fíbula, utilizado no modelo proposto, provou ser resistente, fornecendo estabilidade imediata à coluna cervical quando submetido à carga em flexão.

\section{REFERÊNCIAS BIBLIOGRÁFICAS}

1. ALLEN, B. L.; FERGUSON, R. L.; LEHMANN, T. R.; O'BRIEN, R. P. A mechanistic classification of closed, indirect fractures and dislocations of the lower cervical spine. Spine, 7:01-27, 1982.

2. ATKINSON, P. J. Variation in trabecular structure of vertebrae with age. Calc. Tiss Res., 1:24-32, 1967.

3. BAILEY, R. W.; BADGLEY, C. E. Stabilization of the cervical spine by anterior fusion. J. Bone Joint Surg.(AM), 42:565-94, 1960.

4. BARROS FILHO, T. E. P.; OLIVEIRA, R. P.; HITA, R. M.; RODRIGUES, N. R.; FRANÇA, A. F.; LEIVAS, T. P. Estudo experimental comparativo em três enxertos ósseos cervicais anteriores. Rev. Bras. Ortop., 30:131-4, 1995.

5. BERNARD, T. N. JR.; WHITECLOUD, T. S. III. Cervical spondylotic Myelopathy and Myeloradiculopathy - Anterior decompression and stabilization with autogenous fíbula strut graft. Clin. Orthop., 221:149-60, 1987.

6. CAPEN, D. A.; GARLAND, M. D.; WATERS, R. L. Surgical stabilization of the cervical spine - A comparative analysis of anterior and posterior spine fusions. Clin. Orthop., 196:229-37, 1985.

7. CLOWARD, R. B. The anterior approach for removal of ruptured cervical disks. J.Neurosurg., 15:602-14, 1958.

8. DEFINO, H. L. A.; FUENTES, A. E. R. ; RUSSO JUNIOR, N. Osteossíntese das lesões traumáticas da coluna cervical baixa (C3-C7). Rev. Bras. Ortop., v.29, p.127-35, 1994.

9. DOI, K.; KAWAI, S.; SIMIURA, S.; SAKAI, K. Anterior cervical fusion using the free vascularized fibular graft. Spine, 13:123944, 1988.

10. ELERAKY, M. A.; LIANOS, C.; SONNTAG, V. K. Cervical corpectomy : report of 185 cases and review of the literature. J. Neurosurg., 90:35-41, 1999.

11. HERCULANO, M. A. Tratamento cirúrgico das lesões traumáticas do segmento médio- inferior da coluna cervical. São Paulo, 1999. p.74. Dissertação (Mestrado) - Escola Paulista de Medicina, Universidade Federal de São Paulo.

12. HU, R.; WILBER, G. Anterior cervical corpectomy for the treatment of complex cervical lesions. Can J. Surg., 36:85-8, 1993.

13. KAUFMAN, H. H.; JONES, E. The principles of bony spinal fusion. Neurosurgery, 24:264-69, 1989.

14. LAMBERT, K. L. The weight-bearing function of the fibula. A strain gauge study. J. Bone Joint Surg.(AM), 53:507-13, 1971.

15. MACHADO, I. R. Estudo experimental do trauma em flexão dos segmentos médio e inferior da coluna cervical. São Paulo, 1993.134p. Dissertação (Mestrado) - Escola Paulista de Medicina, Universidade Federal de São Paulo.

16. MACHADO, I. R. Estudo experimental comparativo da fixação posterior do segmento subaxial da coluna cervical através das técnicas de aramagem sublaminar, interespinhosa e placas de

\section{CONCLUSION}

It is concluded that the tested biomechanical model was shown to be adequate to the proposed objective, being useful for analysis of different types of cervical stabilizations, and that fibular cortical bone graft, used in the proposed model, proved to be resistant, giving immediate stability to cervical spine when submitted to flexion load.

ROY-CAMILLE, em cadáveres humanos. São Paulo, 1996. 100p. Tese (Doutorado) - Faculdade de Medicina, Universidade de São Paulo.

17. MARTIN, J. G. JR.; HAID, R. W. JR.; MACMILLAN, M.; RODTS, G. E. JR.; BERKMAN, R. Anterior cervical discectomy with freeze-dried fibula allograft. Spine, 24:852,59, 1999.

18. PANJABI, M. M. Biomechanical evaluation of spinal fixation devices: I. A conceptual framework. Spine, 13:1129-34, 1988.

19. RAO, S.; MEKELLOP, H.; CHAO, D.; SCHILDHAUER, T. A.; GENDLER, E. L.; MOORE, T. M. Biomechanical comparison of bone graft used in anterior spinal reconstruction. Clin. Orthop., 289:131-35, 1993.

20. ROAF, R. A study of the mechanics of spinal injuries. J. Bone Joint Surg., 42(B):810-23, 1960.

21. ROBINSON, R. A.; SMITH, G. W. - Anterolateral cervical disc removal and interbody fusion for cervical disc syndrome. Bull. Johns Hopkins Hops., 96:223-24, 1955.

22. ROSSI, J. D. M. B. A.; BARROS FILHO, T. E. P.; BOLLINGER NETO, R.; LEIVAS, T. P.; LUZO, C. A. M.; NOVO, J. R. T. Amarria interespinhosa versus amarria sublaminar. Estudo experimental Comparativo. Rev. Bras. Ortop., 22:79-83, 1987.

23. SEGAL, H. D.; HARWAY, R. A. The use of fibular grafts with anterior cervical fusion. Orthop. Review, 21:367-9, 1992.

24. SHIMANO, A. C., PAULIN, J. B. P., MORO, C. A., TERRA, O., PEREIRA, L. H., MAZZOCATO, F. C. Projeto de uma Máquina Universal com recursos para testes de material biológico. Rev. Bras. Engnh., 7:391-7, 1990.

25. SMITH, M. D.; CODY, D. D. Load-Bearing capacity of corticocancellous bone grafts in the spine. J. Bone Joint Surg., 75(A):1206-13, 1993.

26. SIMMONS, E. H.; BHALLA, S. K. Anterior cervical discectomy and fusion. A clinical and biomechanical study with eight-year follow up. J. Bone Joint Surg., 51(B):225-37, 1969.

27. TEBET, M. A.; BARROS FILHO, T. E. P.; MACHADO, I. R.; PAULIN, J. B. P.; SHIMANO, A. C. Estudo biomecânico por impacto do mecanismo de flexão com rotação axial da coluna cervical de cadáveres. Acta Ortop. Bras. 7(1):29-44, 1999.

28. WANG, G. J.; ROGER, S. L.; SHAO, Z. H.; MORTON, C. L.; SHAMP, W. G. Comparative strength of anterior spinal fusion with bone graft or polymethylthacrylate. Clin. Orthop., 188:303-8, 1984.

29. WHITECLOUD, T.; La ROCCA, H. Fibular strut graft in reconstructive surgery of the cervical spine. Spine, 1:33, 1976.

30. WITTENBERG, R. H.; MOELLER, J.; SHEA, M.; WHITE III, A. A.; HAYSES, W. C. Compressive strenght of autologous and allogenous bone grafts for throracolumbar and cervical spine fusion. Spine, 15:1073-78, 1990. 